\title{
Survey on Artificial Intelligence Based Autonomous Inspection Systems for an Industry 4.0
}

\author{
G. Shanmugasundar, M. Goutham
}

Associate Professor Mechanical Engineering, Sri Sai Ram Institute of Technology, Chennai, Tamil Nadu, India. Department of Mechanical Engineering, Sri Sai Ram Institute of Technology, Chennai, Tamil Nadu, India.

*Corresponding author Email:shanmugasundar.mech@sairamit.edu.in

\begin{abstract}
The main idea of this project is to inspect the manufactured component through machine vision system .Through this project mainly the dimension correctness of the manufactured component is tested .The aim of the project is to improve the quality of the product. The various parts of the automatic inspection machine includes conveyors ,test table ,inspection camera, rejection bin ,image processing unit, monitoring system . Firstly, the specimen to be inspected is taken to the rotating test table by means of a conveyors. Then the inspection camera's detect the specimen under study on the rotating test table and the image of the specimen is captured by the camera and taken for further processing .The image is processed in terms of pixels by the image processing system. The generated image of the specimen is compared with the standard specimen by the image processing system and the result of inspection is projected on the monitoring system. The rejected specimen is automatically taken to the rejection bin by means of nozzle systems. This process is again repeated for every specimen. The overall setup of the machine is bridge type so it could be possible to inspect more than one work piece at a time.
\end{abstract}

\section{Introduction}

Quality inspection is one of the key aspects of the product development phase The Artificial Intelligence based inspection machine is used for the automatically inspect the manufactured product and ensure the dimensional correctness of the product. This project is based on various literature studies. The supply of defect-free, high-quality products is an important success factor for the long-term competitiveness of manufacturing companies. Despite the increasing challenges of rising product variety and complexity and the necessity of economic manufacturing, a comprehensive and reliable quality inspection is often indispensable. In consequence, high inspection volumes turn inspection processes into manufacturing bottlenecks. This technology involved in the use of various technologies like machine learning and cloud technologies. A holistic approach was proposed which included the processing the image, image enhancement, target-oriented data acquisition and processing, modelling and model deployment as well as the technological implementation. A real industrial use case in SMT manufacturing is presented to underline the procedure and benefits of the proposed method. The results show that by employing the proposed method, inspection volumes can be reduced significantly and thus economic advantages can be generated. As a result of increasing competitive pressure, the supply of high-quality products continues to evolve as an important competitive factor to secure the long-term success of a company. In order to guarantee the delivery and transfer of zero-defect products, it is essential to ensure a constantly high quality for all products. Additionally, in the ever-growing personalization paradigm, the number of variants and thus the complexity of inspection planning and operation increase tremendously. The design of inspection processes is therefore an extremely important and economically critical procedure, which requires the application of the latest and most sophisticated technologies. In the era of Industry 4.0, appliances are enabled to bring benefits, including personalization, prediction, energy savings, defect reductions, and quality improvement. Industry 4.0 denotes the trend towards automation and data exchange in manufacturing technologies and processes, including Cyber-Physical Systems (CPS), the Internet of Things (IoT), cloud computing, and Artificial Intelligence (AI) CPS constitute a new generation of systems with integrated computational and physical capabilities that enable the interaction with humans through new modalities. The IoT is designated a key enabler for the next generation of advanced manufacturing, describing the technologies of a global infrastructure which allows to connect physical and virtual objects through information and communication technologies (ICT). Non-destructive testing is mostly used in the industry, among them the visual-based approach for fault detection is one of the most common procedures. Images captured by the camera or processed by a neural network, which is trained to detect and localize the defect. Once the visual inspection system is confident about type of problem and its location, it follows the pre-set instructions like sending a notification or executing other operations. In production of juice bottles during production bottles can get damaged which can lead to additional cost, problems whiletransportation which ultimatelycausestrouble for the company. Visual inspection system based on the computer vision model detects this mismatch and notifies us in real time so that the defective piece can be excluded before they reach the final packaging stage. This system is very helpful when it comes to safety of factory worker, it can be used to detect whether the person is wearing its safety measures like gloves, helmet, goggles, shoes. The neural network system is able to analyses this by monitoring cameras and then they notify about the violation. The training of neutral system is a 
important aspect in the process of inspection. A trained neural network provides igh inspection accuracy. The network can be trained with many images of different objects. The network of neural system depends on the task image specification objectdetection or semantic segmentation pending on how precisely we would like to detect defect. Define the task and train the network so as to detect any deviations from the standard appearance Not only on the part of inspection but Artificial intelligence based inspection has its applications on road safety inspection as well.Research on damage detection of road surfaces using image processing techniques has been actively conducted, achieving considerably high detection accuracies. Many studies only focus on the detection of the presence or absence of damage. However, in a real-world scenario, when the road managers from a governing body need to repair such damage, they need to clearly understand the type of damage in order to take effective action. In addition, in many of these previous studies, the researchers acquire their own data using different methods. Hence, there is no uniform road damage dataset available openly, leading to the absence of a benchmark for road damage detection. This study makes three contributions to address these issues. First, to the best of our knowledge, for the first time, a large-scale road damage dataset is prepared. This dataset is composed of 9,053 road damage images captured with a smartphone installed on a car, with 15,435 instances of road surface damage included in these road images. In order to generate this dataset, a study with 7 municipalities in Japan and acquired road images for more than 40 hours. These images were captured in a wide variety of weather and illuminance conditions. In each image, an annotation like bounding box representing the location and type of damage. Next, we used a state-of-the-art object detection method using convolutional neural networks to train the damage detection model with our dataset, and compared the accuracy and runtime speed on both, using a GPU server and a smartphone. Finally, a demonstrates the type of damage can be classified into eight types with high accuracy by applying the proposed object detection method. The road damage dataset, our experimental results, and the developed smartphone application used in this study are publicly available.

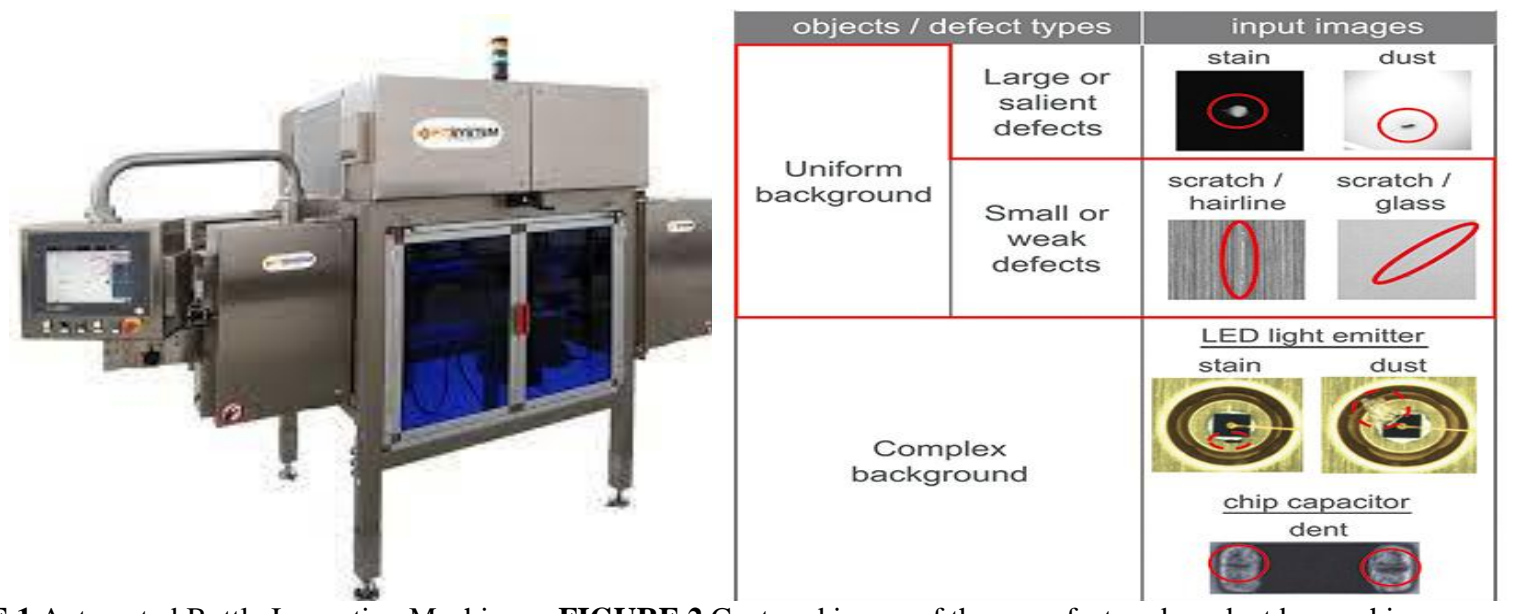

FIGURE 1.Automated Bottle Inspection Machine FIGURE 2.Captured image of the manufactured product by machine vision system

\section{Literature Reviews}

\begin{tabular}{|c|l|l|l|l|}
\hline SI.NO & TITLE & AUTHOR'S & YEAR & \multicolumn{1}{c|}{ INFERENCE } \\
\hline 1. & $\begin{array}{l}\text { Road Damage } \\
\text { Inspection }\end{array}$ & $\begin{array}{l}\text { Hiroya Maeda } \\
\text {,YoshihideSekimeto } \\
\text {,Toshikazu Seto } \\
\text {,Takehiro Kashiyama } \\
\text {,Hiroshi Omata. }\end{array}$ & January 2018 & $\begin{array}{l}\text { They propose the usage of AI for inspection of roads } \\
\text { to ensure the road safety due to various factors. using } \\
\text { a state-of-the-art object detection method using } \\
\text { convolutional neural networks to train the damage } \\
\text { detection model with the dataset, and compared the } \\
\text { accuracy and runtime speed on both, using a GPU } \\
\text { server and smartphone. }\end{array}$ \\
\hline 2. & $\begin{array}{l}\text { AI Inspection: } \\
\text { Fomputer Vision } \\
\text { For Visual } \\
\text { Inspection }\end{array}$ & $\begin{array}{l}\text { AmrutaMohite } \\
\text {,Atherva Kulkarni } \\
\text {,RutwikChithis } \\
\text {,Swapnil Mane } \\
\text {,ShubhamAsabe. }\end{array}$ & January 2021 & $\begin{array}{l}\text { The review paper explains about computer based } \\
\text { visual inspection, comparison between human and } \\
\text { computer vison system, its development, } \\
\text { improvements and applications. }\end{array}$ \\
\hline 3. & $\begin{array}{l}\text { Inspection } \\
\text { machine defect } \\
\text { detection based } \\
\text { on deep learning }\end{array}$ & $\begin{array}{l}\text { HanzawaYuki,Ikeda } \\
\text { YasuyukiKiruta } \\
\text {,Manashi ,Hasiwaga } \\
\text { Yuki. }\end{array}$ & October 2021 & $\begin{array}{l}\text { This paper explains us about training neural networks } \\
\text { with help of images of defects .It uses machine } \\
\text { learning and Artificial intelligence that imitates the } \\
\text { way humans gain certain knowledge. }\end{array}$ \\
\hline
\end{tabular}


M. Goutham. et.al / Design, Modelling and Fabrication of Advanced Robots 1(1) 2022, 6-14

\begin{tabular}{|c|c|c|c|c|}
\hline 4. & $\begin{array}{l}\text { Inspection } \\
\text { machine based } \\
\text { on Machine } \\
\text { learning and } \\
\text { cloud computing }\end{array}$ & $\begin{array}{l}\text { JochenBoing } \\
\text {,ThorbjornBorggrafe } \\
\text {,GunterBeitinger } \\
\text {,JochenDeuse. }\end{array}$ & $\begin{array}{l}\text { OMRON } \\
\text { TECHNICS } \\
\text { Vol.51 } \\
\text { September } \\
2019 .\end{array}$ & $\begin{array}{l}\text { A pre-training type defect-detection algorithm that } \\
\text { could handle a variety of objects and defect types. } \\
\text { Through the proposed method, we verified that the } \\
\text { algorithm could also handle objects and defects with } \\
\text { unknown patterns. }\end{array}$ \\
\hline 5. & $\begin{array}{l}\text { Special purpose } \\
\text { Inspection } \\
\text { Machine }\end{array}$ & $\begin{array}{l}\text { AB Plastomech, } \\
\text { Bangalore. }\end{array}$ & $\begin{array}{l}\text { Advanced } \\
\text { Engineering } \\
\text { Informatics, } \\
2020\end{array}$ & $\begin{array}{l}\text { This Artificial Intelligence based inspection machine } \\
\text { uses bowl feeder to take the test specimen to rotating } \\
\text { test table. The machine vision camera captures the } \\
\text { image of specimen and based on the results the defect } \\
\text { is automatically rejected. }\end{array}$ \\
\hline 6. & $\begin{array}{l}\text { 3D defect } \\
\text { detection using } \\
\text { photometric } \\
\text { stereo illusion }\end{array}$ & $\begin{array}{l}\text { Jong Hyuk Lee, } \\
\text { Hyum Min On ,Min } \\
\text { Young Kim. }\end{array}$ & $\begin{array}{l}\text { International } \\
\text { Conference on } \\
\text { Artificial } \\
\text { Intelligence } \\
2019\end{array}$ & $\begin{array}{l}\text { The 3D defect inspection involves the use of laser } \\
\text { sensors to ensure 3Dimensional inspection of the } \\
\text { work piece and also the use of photometric stereo } \\
\text { illusion systems. }\end{array}$ \\
\hline 7. & $\begin{array}{l}\text { Quality control } \\
\text { inspection } \\
\text { opportunities } \\
\text { using deep } \\
\text { learning }\end{array}$ & $\begin{array}{l}\text { VladimirsSatrevics } \\
\text {,GundarsKulikovskis } \\
\text {,Oskars Oss. }\end{array}$ & $\begin{array}{l}24^{\text {th }} \text { World } \\
\text { Multi } \\
\text { conference on } \\
\text { Systematics } \\
\text { Cybernets and } \\
\text { Informatics } \\
2020\end{array}$ & $\begin{array}{l}\text { To meet industry standard quality inspectors in } \\
\text { manufacturing firms inspect product quality usually } \\
\text { after the product is manufactured in order to reduce } \\
\text { time consuming inspection. }\end{array}$ \\
\hline 8. & $\begin{array}{lr}\text { Fracture } & \\
\text { detection } & \text { using } \\
\text { machine } & \text { vision } \\
\text { and } & \text { neural } \\
\text { network } & \end{array}$ & Sarthak J Shetty. & January 2019 & $\begin{array}{l}\text { They propose the usage of Opens an open source } \\
\text { computer vision framework developed by Google.to } \\
\text { accomplish the task of detection and prediction of } \\
\text { presence of surface defects such as fracture of gears }\end{array}$ \\
\hline 9. & $\begin{array}{l}\text { Machine Vision } \\
\text { application in } \\
\text { Industrial } \\
\text { application }\end{array}$ & Diego Gonzales. & January 2021 & $\begin{array}{l}\text { They propose that machine vision is the technology } \\
\text { used to provide imaging based automatic inspection } \\
\text { and analysis for such application as automatic } \\
\text { inspection, process control and robot guidance. }\end{array}$ \\
\hline 10. & $\begin{array}{l}\text { Automatic } \\
\text { Inspection } \\
\text { System using } \\
\text { machine vision }\end{array}$ & $\begin{array}{l}\text { U.S.Khan ,M.A.Khan } \\
\text {,J.Iqbal. }\end{array}$ & $\begin{array}{l}34^{\text {th }} \text { Applied } \\
\text { Imagery and } \\
\text { pattern } \\
\text { Recognition } \\
\text { Workshop }\end{array}$ & $\begin{array}{l}\text { Machine vision system integrated electronic } \\
\text { components with software systems to imitate a } \\
\text { variety of human functions. The technique discussed } \\
\text { in this paper inspects on basic pixel level image } \\
\text { processing. }\end{array}$ \\
\hline 11. & $\begin{array}{l}\text { Bone fracture } \\
\text { Detection and } \\
\text { Classification } \\
\text { using deep } \\
\text { learning }\end{array}$ & $\begin{array}{l}\text { D.P. Yadav, Sandeep } \\
\text { Rathor }\end{array}$ & $\begin{array}{l}2020 \\
\text { International } \\
\text { Conference on } \\
\text { Power } \\
\text { Electronics } \\
\text { \&IoT } \\
\text { Applications in } \\
\text { Renewable } \\
\text { Energy and its } \\
\text { Control (PARC) } \\
\text { Feb. 2020 }\end{array}$ & $\begin{array}{l}\text { The fracture in bone mainly occurs due to bad fall. } \\
\text { The usage of MRI and X-rays. The purpose of the } \\
\text { project is to involving neural network technology to } \\
\text { detect and monitor cracks in bones a deep neural } \\
\text { network model has been developed to classify the } \\
\text { fracture and healthy bone has been proposed. }\end{array}$ \\
\hline 12. & $\begin{array}{l}\text { Bone Fracture } \\
\text { detection using } \\
\text { ML and Digital } \\
\text { Geometry. }\end{array}$ & $\begin{array}{l}\text { Ashosh Sharma, } \\
\text { Abisek Mishra, Aashi } \\
\text { Bansal }\end{array}$ & September 2021 & $\begin{array}{l}\text { The usage of orthopedic X-ray imaging for bone } \\
\text { fracture detection and deployment of Machine } \\
\text { learning techniques to detect and cure bone fractures. }\end{array}$ \\
\hline 13. & $\begin{array}{l}\text { Intelligent } \\
\text { Machine Vision } \\
\text { Model for } \\
\text { Defective } \\
\text { Product } \\
\text { Inspection Based } \\
\text { on Machine } \\
\text { Learning }\end{array}$ & $\begin{array}{l}\text { TajeddineBenbararra } \\
\text { d, } \\
\text { MarouaneSalhoui,So } \\
\text { ukainaBakhatKenitar }\end{array}$ & $\begin{array}{lr}\text { J. } & \text { Sens. } \\
\text { Actuator Netw. } \\
2021\end{array}$ & $\begin{array}{l}\text { The proposed model in exploits all generated data by } \\
\text { various integrated technologies in the manufacturing } \\
\text { chain, suggesting two types of algorithms and method } \\
\text { based identification }\end{array}$ \\
\hline
\end{tabular}


M. Goutham. et.al / Design, Modelling and Fabrication of Advanced Robots 1(1) 2022, 6-14

\begin{tabular}{|c|c|c|c|c|}
\hline 14. & $\begin{array}{l}\text { AI based sensors } \\
\text { for Forest Fires } \\
\text { detection and AI } \\
\text { based systems for } \\
\text { Stopping the } \\
\text { Spread }\end{array}$ & Nidhika Yadav & September 2021 & $\begin{array}{l}\text { The proposed paper suggests the usage of the } \\
\text { machine vision system for the detection of forest fires } \\
\text { and extinguishing it by the help of gray scale imaging }\end{array}$ \\
\hline 15. & $\begin{array}{l}\text { AI-based } \\
\text { Automatic } \\
\text { Optical } \\
\text { Inspection of } \\
\text { Glass Bubble } \\
\text { Defects }\end{array}$ & $\begin{array}{l}\text { Jing wien, Chiang } \\
\text { wang, Chiehcheng }\end{array}$ & $\begin{array}{l}\text { MSIE April } \\
2020\end{array}$ & $\begin{array}{l}\text { The work that for the detection of bubble defects in } \\
\text { spherical glass, the lighting mechanism, the image } \\
\text { acquisition method, as well as the detection } \\
\text { algorithm, must be designed together to achieve a } \\
\text { high accuracy performance. The initial experimental } \\
\text { results validate the feasibility of the proposed AOI } \\
\text { method with an accuracy of } 95 \% \text {. }\end{array}$ \\
\hline 16. & $\begin{array}{l}\text { A Large-scale, } \\
\text { High-quality for } \\
\text { Dataset fatection }\end{array}$ & $\begin{array}{l}\text { Shuai shao, Zeming } \\
\mathrm{Li} \text {, Tianyuan Zhang, } \\
\text { Chao peng. }\end{array}$ & $\begin{array}{l}2019 \text { IEEE/CVF } \\
\text { International } \\
\text { Conference on } \\
\text { Computer } \\
\text { Vision }\end{array}$ & $\begin{array}{l}\text { In this paper, we present a large-scale, high-quality } \\
\text { object detection dataset, Objects } 365 \text {, which } \\
\text { establishes a } \\
\text { new challenge and benefits the many existing } \\
\text { localization sensitive vision tasks. In the future, we } \\
\text { plan to investigate } \\
\text { bigger models than ResNet-50. }\end{array}$ \\
\hline 17. & $\begin{array}{l}\text { Survey on Deep } \\
\text { Learning-Based } \\
\text { Marine Object } \\
\text { Detection }\end{array}$ & $\begin{array}{l}\text { Ruolan Zhang, } \\
\text { Shaoxi Li, Guanfeng } \\
\text { Ji, Jing Li }\end{array}$ & November 2021 & $\begin{array}{l}\text { This survey covers most of the application scenarios } \\
\text { of object } \\
\text { detection for maritime surveillance and autonomous } \\
\text { ship navigation. In recent years, a large number of } \\
\text { marine object } \\
\text { detection models based on deep learning have been } \\
\text { proposed, } \\
\text { but due to the lack of universal evaluation criteria, it } \\
\text { is difficult to compare different improved models. }\end{array}$ \\
\hline 18. & $\begin{array}{l}\text { Particle shape } \\
\text { analysis of coarse } \\
\text { aggregate using } \\
\text { digital image } \\
\text { processing }\end{array}$ & $\begin{array}{l}\text { A.K.H. Kwan, C.F. } \\
\text { Mora, H.C. Chan }\end{array}$ & October 1998 & $\begin{array}{l}\text { Although the thickness and volume of the particles } \\
\text { are not } \\
\text { measured, this DIP method is capable of producing } \\
\text { the mean thickness/breadth ratio of the aggregate and } \\
\text { shape measurement results in terms of mass fractions. } \\
\text { For the purpose of verification, the shape } \\
\text { measurement results obtained } \\
\text { by the proposed DIP method have been compared to } \\
\text { those obtained by traditional mechanical sieving and } \\
\text { manual gauging. }\end{array}$ \\
\hline 19. & $\begin{array}{ll}\text { Particle Shape } \\
\text { Analysis as an } \\
\text { Example } & \text { of } \\
\text { Knowledge } & \\
\text { Extraction by } & \\
\text { Neural Nets }\end{array}$ & $\begin{array}{l}\text { ReinhardKohlus, } \\
\text { Michael Bottlinger }\end{array}$ & April 1993 & $\begin{array}{l}\text { In technical problems which are concerned with the } \\
\text { extraction } \\
\text { of features such as particle shape analysis, neural nets } \\
\text { might be } \\
\text { an appropriate way to determine the relationship } \\
\text { between data and effect. As shown by the example of } \\
\text { particle shape analysis, unsupervised learning } \\
\text { networks such as self-organizing maps or adaptive } \\
\text { resonance theory (ART) networks can be very useful. }\end{array}$ \\
\hline 20. & $\begin{array}{lr}\text { Particle } & \text { shape } \\
\text { analysis } & \text { of } \\
\text { tailings } & \text { using } \\
\text { digital } & \text { image } \\
\text { processing } & \end{array}$ & $\begin{array}{l}\text { Yonghao yang } \\
\text {,Zuoan Wei , Andy } \\
\text { Fourier, Yulong Chen } \\
\text {. }\end{array}$ & July 2019 & $\begin{array}{l}\text { The paper suggests the elongation of tailings } \\
\text { decreases with the increment } \\
\text { of the particle size, which means the shape of tailings } \\
\text { tends to be needle-like or columnar with the decreases } \\
\text { of particle size. The elongation of sea sand shows a } \\
\text { similar pattern of variation law. }\end{array}$ \\
\hline 21. & $\begin{array}{l}\text { R-CNN-Based } \\
\text { Large-Scale } \\
\text { Object-Defect } \\
\text { Inspection } \\
\text { System for } \\
\text { Laser Cutting in } \\
\text { the Automotive } \\
\text { Industry }\end{array}$ & $\begin{array}{l}\text { DonggyunIm } \\
\text { JongpilJeong . }\end{array}$ & November 2021 & $\begin{array}{l}\text { This paper presents RODIS to perform defect } \\
\text { inspection of large objects, such as side-outers. In } \\
\text { particular,the lack of FoVs that resulted from the } \\
\text { inappropriate combination of camera shutter types } \\
\text { and lenses, and the image noise that occurs when } \\
\text { multiple cameras are operated simultaneously, should } \\
\text { be considered during similar research tasks. }\end{array}$ \\
\hline
\end{tabular}


M. Goutham. et.al / Design, Modelling and Fabrication of Advanced Robots 1(1) 2022, 6-14

\begin{tabular}{|c|c|c|c|c|}
\hline 22. & $\begin{array}{l}\text { Systematic } \\
\text { method for } \\
\text { Machine learning } \\
\text { and } \\
\text { manufacturing } \\
\text { system. }\end{array}$ & $\begin{array}{l}\text { Simon , Christoper } \\
\text { prince }\end{array}$ & $\begin{array}{l}\text { 53rd CIRP } \\
\text { Conference on } \\
\text { Manufacturing } \\
\text { Systems }\end{array}$ & $\begin{array}{l}\text { The SLR at hand analyzed the current state of the art } \\
\text { of recent years (2015-2020) with a strong focus on } \\
\text { actual implementations and direct naming of used } \\
\text { machine learning algorithms in the factory } \\
\text { environment for each literature. }\end{array}$ \\
\hline 23. & $\begin{array}{l}\text { Automated } \\
\text { Surface Defect } \\
\text { Inspection Based } \\
\text { on Autoencoders } \\
\text { and Fully } \\
\text { Convolutional } \\
\text { Neural Networks }\end{array}$ & $\begin{array}{lrr}\text { Cheng } & \text { Wie, } & \text { Li } \\
\text { Zhang, } & \text { Ming } & \text { Tai, } \\
\text { Yun Jie. } & & \end{array}$ & Appl. Sci. 2021 & $\begin{array}{l}\text { The experimental results have revealed the } \\
\text { effectiveness of the proposed algorithm for surface } \\
\text { inspection. Only normal samples are required for the } \\
\text { proposed algorithm. A simple data augmentation } \\
\text { scheme is adopted for the generation of defective } \\
\text { images for the training of the neural networks. This } \\
\text { could facilitate the collection of a training set for the } \\
\text { algorithm. In addition, the ability for the self- } \\
\text { generation of the template by the AE for an input test } \\
\text { image is beneficial for lifting the restriction on the } \\
\text { synchronization between } \\
\text { the position of the test image and the template. }\end{array}$ \\
\hline 24. & $\begin{array}{l}\text { Analysis of Laser } \\
\text { Sensors and } \\
\text { Camera Vision in } \\
\text { the Shoe Position } \\
\text { Inspection } \\
\text { System }\end{array}$ & $\begin{array}{l}\text { JaromírKlarák, Ivan } \\
\text { Kuric, Ivan Zaja cko } \\
\text { VladimírBulej , } \\
\text { VladimírTlach and } \\
\text { Jerzy Józwik }\end{array}$ & November 2021 & $\begin{array}{l}\text { In This paper, there are two methodologies of } \\
\text { performing inspection issues for the } \\
\text { shoe industry described. In the first case, it was the } \\
\text { method of capturing } 12 \mathrm{Mpx} \text { images by camera } \\
\text { vision. These data were used to evaluate the position } \\
\text { of the upper on the last. Evaluating was performed by } \\
\text { processing image, edge detection, and final DBSCAN } \\
\text { clustering, separating white pixels to edges. }\end{array}$ \\
\hline 25. & $\begin{array}{l}\text { Machine learning } \\
\text { applied to the } \\
\text { design and } \\
\text { inspection of } \\
\text { reinforced } \\
\text { concrete bridges: } \\
\text { Resilient } \\
\text { methods and } \\
\text { emerging } \\
\text { applications }\end{array}$ & $\begin{array}{l}\text { Weiying Fan, Yao } \\
\text { Chen, Jiaqiang Li, } \\
\text { Yue Sun, Jian Feng } \\
\text { a, Hany Hassanin }\end{array}$ & July 2021 & $\begin{array}{l}\text { This study summarized the applications of machine } \\
\text { learning (ML) in reinforced concrete bridges, from } \\
\text { design to inspection. It demonstrates that ML has } \\
\text { great computing power and image processing } \\
\text { capability for dealing with different aspects of } \\
\text { reinforced concrete bridges. Once an ML model is } \\
\text { trained, the prediction efficiency is significantly high. } \\
\text { It surpasses the speed of traditional structural damage } \\
\text { recognition and strength prediction methods, realizing } \\
\text { nearly real-time performance. }\end{array}$ \\
\hline 26. & $\begin{array}{l}\text { Machine learning } \\
\text { based malicious } \\
\text { payload } \\
\text { identification }\end{array}$ & $\begin{array}{l}\text { Qiumei Cheng, } \\
\text { Chunming Wu , } \\
\text { Haifeng Zhou , } \\
\text { Dezhang Kong , } \\
\text { Dong Zhang, } \\
\text { Junchi Xing , Wei } \\
\text { Ruan. }\end{array}$ & August 2021 & $\begin{array}{l}\text { Deep packet inspection (DPI) in software-defined } \\
\text { networking (SDN) } \\
\text { remains restrictions in the presence of a large volume } \\
\text { of data. Despite third-party DPI tools, this paper } \\
\text { proposes a novel OpenFlow-enabled deep packet } \\
\text { inspection (OFDPI) approach in SDN using machine } \\
\text { learning algorithms. OFDPI enables deep packet } \\
\text { inspection for both unencrypted traffic and encrypted } \\
\text { traffic by training two binary classifiers respectively }\end{array}$ \\
\hline 27. & $\begin{array}{lr}\text { Machine } & \text { vision } \\
\text { based } & \text { control } \\
\text { system } & \\
\end{array}$ & $\begin{array}{l}\text { Aditya Akundi } \\
\text { Mark Reyna, }\end{array}$ & June 2021 & $\begin{array}{l}\text { Quality control is a critical issue in all industries that } \\
\text { MV systems are assisting in. The MV system } \\
\text { proposed in this paper offers a simple setup capable } \\
\text { of identifying defects in diverse shapes. As shown, } \\
\text { the system could identify defects in cubes, cylinders, } \\
\text { and sinusoidal objects Furthermore, it is essential that } \\
\text { effective MV systems identify minute defects in } \\
\text { objects. }\end{array}$ \\
\hline 28. & $\begin{array}{l}\text { Exploring impact } \\
\text { and features of } \\
\text { machine vision } \\
\text { for progressive } \\
\text { industry } \\
4.0 \text { culture }\end{array}$ & $\begin{array}{l}\text { MohdJavaid, Abid } \\
\text { Haleem , Ravi Pratap } \\
\text { Singh, ShanayRab , } \\
\text { Rajiv Suman }\end{array}$ & October & $\begin{array}{l}\text { MV is the approach of industrial automation and } \\
\text { related technology. It can be implemented for } \\
\text { automated visual inspection, which can overcome } \\
\text { several business problems. The technology of } \\
\text { machine vision replaced human quality checks } \\
\text { steadily. It offers different precision \& durability in } \\
\text { the identification of objects. MV is beneficial for } \\
\text { Industry } 4.0 \text { to improve accuracy, productivity, and } \\
\text { overall efficiency to increase traceability of their }\end{array}$ \\
\hline
\end{tabular}




\begin{tabular}{|c|c|c|c|c|}
\hline & & & & $\begin{array}{l}\text { goods. Here industrial equipment uses highly faithful } \\
\text { cameras to capture digital environmental pictures or a } \\
\text { workpiece to utilise a computer vision system. }\end{array}$ \\
\hline 29. & $\begin{array}{l}\text { Online quality } \\
\text { inspection of } \\
\text { ultrasonic } \\
\text { composite } \\
\text { welding by } \\
\text { combining } \\
\text { artificial } \\
\text { intelligence } \\
\text { technologies with } \\
\text { welding process } \\
\text { signatures }\end{array}$ & $\begin{array}{l}\text { Yang Li , Bo Yu, } \\
\text { Baicun Wang , Tae } \\
\text { Hwa } \\
\text { MihaelaBanu. }\end{array}$ & 20 June 2020 & $\begin{array}{l}\text { This study investigates the prediction of the failure } \\
\text { load and weld quality level (under weld, normal weld, } \\
\text { and over weld) in ultrasonic CRFTP welding } \\
\text { simultaneously using AI technologies, including } \\
\text { ANN and RFmodels. These two models have eight } \\
\text { common inputs (the duration and net acoustic wave } \\
\text { energy in stages } 1,2,3 \text {, and } 4 \text {, respectively,) extracted } \\
\text { from the process signatures. The findings of this } \\
\text { study can } \\
\text { contribute to the online quality inspection of } \\
\text { ultrasonic composite welding and further aid } \\
\text { industrial applications. }\end{array}$ \\
\hline 30. & $\begin{array}{l}\text { Systematic } \\
\text { literature review } \\
\text { of validation } \\
\text { methods for AI } \\
\text { systems }\end{array}$ & $\begin{array}{l}\text { LalliMyllyaho*, } \\
\text { MikkoRaatikainen, } \\
\text { TomiMännistö, } \\
\text { TommiMikkonen, } \\
\text { Jukka K. Nurminen }\end{array}$ & 28 July 2021 & $\begin{array}{l}\text { a systematic literature review on the validation } \\
\text { methods of AI systems based on } 90 \text { primary studies. } \\
\text { The primary studies represent } 14 \text { domains carrying } \\
\text { out } 18 \text { tasks and their impact on malfunction ranges } \\
\text { from nuisance to lethal, which demonstrates a wide } \\
\text { variety and broad application of AI technologies. As } \\
\text { our selection focused on studies with solid empirical } \\
\text { evidence, these studies represent relatively mature } \\
\text { practical applications rather than immature solution } \\
\text { proposals in early-stage research. However, most of } \\
\text { these systems applied ML }\end{array}$ \\
\hline 31. & $\begin{array}{l}\text { Survey Paper on } \\
\text { Visual Inspection } \\
\text { of a } \\
\text { Mechanical Part } \\
\text { using Machine } \\
\text { Learning }\end{array}$ & $\begin{array}{l}\text { Priya Charles , } \\
\text { Simrangupta } \\
\text {,NirajBhodhoria }\end{array}$ & January 2020 & $\begin{array}{l}\text { A non-contact visual inspection system with } \\
\text { minimum manual } \\
\text { intervention. Flexible over wide range of products } \\
\text { and their } \\
\text { defect characteristics. Supervised learning algorithm } \\
\text { trains the model which then classifies the input image } \\
\text { into given classes. The output can lead to re- } \\
\text { machining, rejection or acceptance of machinery part. } \\
\text { The automated visual inspection is consistent and } \\
\text { precise, leading to an increase in quality } \\
\text { assurance factor. }\end{array}$ \\
\hline 32. & $\begin{array}{l}\text { Survey } \\
\text { identifying } \\
\text { Artificial } \\
\text { intelligence for } \\
\text { Field application }\end{array}$ & Bernd Kuhlencotter & $\begin{array}{l}\text { 52rd CIRP } \\
\text { Conference on } \\
\text { Manufacturing } \\
\text { Systems }\end{array}$ & $\begin{array}{l}\text { The fact that unsupervised methods are only } \\
\text { mentioned twice might be due to the fact, that the } \\
\text { actual data preparation and exploration were not } \\
\text { described as detailed as the implemented regression } \\
\text { or classification task in many publications. The } \\
\text { authors are of the opinion that way more } \\
\text { implementations make use of unsupervised methods } \\
\text { along the whole data analysis pipeline even though } \\
\text { they are not mentioned explicitly. }\end{array}$ \\
\hline 33. & $\begin{array}{l}\text { QoS aware } \\
\text { Traffic } \\
\text { Classification } \\
\text { Architecture }\end{array}$ & $\begin{array}{l}\text { Yuxiang } \\
\text { „JiachoXie . }\end{array}$ & $\begin{array}{l}\text { 8th International } \\
\text { conference on } \\
\text { Communication } \\
\text { system }\end{array}$ & $\begin{array}{l}\text { In this paper, they propose a SDN flow classification } \\
\text { architecture based on DPI and semi-supervised } \\
\text { learning of multi-classifier. Subsequently, we test the } \\
\text { performance and verify the superiority of the } \\
\text { proposed architecture with realistic network traffic } \\
\text { data. Architecture can implement efficient traffic } \\
\text { classification with high accurate. }\end{array}$ \\
\hline
\end{tabular}


M. Goutham. et.al / Design, Modelling and Fabrication of Advanced Robots 1(1) 2022, 6-14

\begin{tabular}{|c|c|c|c|c|}
\hline 34. & $\begin{array}{l}\text { Legal aspects of } \\
\text { data cleansing in } \\
\text { medical AI }\end{array}$ & $\begin{array}{l}\text { Karl Stöger, David } \\
\text { Schneebergerb, Peter } \\
\text { Kieseberg, Andreas } \\
\text { Holzinger }\end{array}$ & September 2019 & $\begin{array}{l}\text { In this paper, we motivate, demonstrate, and justify } \\
\text { why data cleaning is important for the quality and } \\
\text { safety of medical AI systems and should not be } \\
\text { underestimated from either a technical or legal } \\
\text { perspective. Data cleansing (of training data) is not } \\
\text { only a technical issue, but also a legal one. In any } \\
\text { case, in the domain of AI and especially Medical AI, } \\
\text { the two disciplines of computer science and law need } \\
\text { to work more closely together. }\end{array}$ \\
\hline 35. & $\begin{array}{l}\text { Artificial } \\
\text { intelligence and } \\
\text { machine learning } \\
\text { for medical } \\
\text { imaging: A } \\
\text { technology } \\
\text { review }\end{array}$ & $\begin{array}{l}\text { Ana Barrag'an- } \\
\text { Montero } \\
\text { UmairJavaid, Gilmer } \\
\text { Vald'es , Dan } \\
\text { Nguyen }\end{array}$ & $18^{\text {th }}$ April 2021 & $\begin{array}{l}\text { In medicine, specialties where images are central, } \\
\text { like radiology, pathology or oncology, have seized } \\
\text { the opportunity and considerable efforts in research } \\
\text { and development have been deployed to transfer the } \\
\text { potential of AI to clinical applications. With AI } \\
\text { becoming a more mainstream tool for typical medical } \\
\text { imaging analysis tasks, such as diagnosis, } \\
\text { segmentation, or classification, the key for a safe and } \\
\text { efficient use of clinical AI applications relies, in part, } \\
\text { on informed practitioners. }\end{array}$ \\
\hline 36. & $\begin{array}{l}\text { Artificial } \\
\text { intelligence- } \\
\text { empowered } \\
\text { pipeline for } \\
\text { image-based } \\
\text { inspection of } \\
\text { concrete } \\
\text { structures }\end{array}$ & $\begin{array}{l}\text { Jun Kang Chow, } \\
\text { Zhaoyu Su, Jimmy } \\
\text { Wu, Zhaofeng Li, Pin } \\
\text { Siang Tan. }\end{array}$ & July 2021 & $\begin{array}{l}\text { In this paper, the feasibility of applying deep learning } \\
\text { techniques in the inspection programs of civil } \\
\text { infrastructure is reported. An AI-empowered } \\
\text { inspection pipeline, which comprises anomaly } \\
\text { detection, anomaly extraction and defect } \\
\text { classification, is built to alleviate the current } \\
\text { assessment practice, which is prone to error, laborious } \\
\text { and time-consuming. In this approach, an anomaly } \\
\text { map is generated to assist in the extraction of } \\
\text { potential defects, and then the suspected defects are } \\
\text { categorized into appropriate classes }\end{array}$ \\
\hline 37. & $\begin{array}{l}\text { Artificial } \\
\text { intelligence and } \\
\text { machine learning } \\
\text { for medical } \\
\text { imaging: A } \\
\text { technology } \\
\text { review }\end{array}$ & $\begin{array}{l}\text { Mats Holmstr"om , } \\
\text { Fredrik L"ofman , } \\
\text { Steven Michiels , } \\
\text { Kevin Souris , } \\
\text { Edmond Sterpin , } \\
\text { John A. Lee }\end{array}$ & $18^{\text {th }}$ April 2021 & $\begin{array}{l}\text { Predictive models are trained based on historic data } \\
\text { sets in the cloudand deployed on local edge devices. } \\
\text { During the manufacturing process,parameters are } \\
\text { recorded and sent to the edge device, on which data } \\
\text { processing and model application are handled in near } \\
\text { real time. Theprediction results are evaluated and } \\
\text { aggregated to a processable levelallowing a dynamic } \\
\text { inspection decision. }\end{array}$ \\
\hline 38. & $\begin{array}{l}\text { Implementation } \\
\text { of AI-Machine } \\
\text { learning for } \\
\text { Machine Safety. }\end{array}$ & $\begin{array}{l}\text { Sara Anastasi } \\
\text {,Marianna Madonna, } \\
\text { Luigi Monica }\end{array}$ & $\begin{array}{l}\text { International } \\
\text { conference on } \\
\text { Industry } 4,0 \text { and } \\
\text { Smart } \\
\text { manufacturing. }\end{array}$ & $\begin{array}{l}\text { The implementation of artificial intelligence and } \\
\text { machine learning will lead to the intelligent machines. } \\
\text { In particular, the analysis identified the EHSRs of the } \\
\text { Machinery Directive which will be most influenced } \\
\text { by the incorporation of AI/ML applications in the } \\
\text { design of the machines, highlighting the changes } \\
\text { needed for the Machinery Directive to guarantee } \\
\text { safety levels for innovative products at least } \\
\text { equivalent to the current ones. }\end{array}$ \\
\hline 39. & $\begin{array}{l}\text { An alert-assisted } \\
\text { inspection policy } \\
\text { for a production } \\
\text { process with } \\
\text { imperfect } \\
\text { condition signals }\end{array}$ & Alp Akcay & $28^{\text {th }}$ May 2021 & $\begin{array}{l}\text { the optimal (s, u) -policy, a stochastic dynamic } \\
\text { programming model is formulated with the objective } \\
\text { of minimizing the long-run expected cost rate. The } \\
\text { performance improvement achieved by the optimal ( } \mathrm{s} \text {, } \\
u \text { ) -policy is quantified by comparing it to the } \\
\text { benchmark policies. The economic value of adding an } \\
\text { alert- triggered inspection option to a conventional } \\
\text { age-based inspection policy is discussed. Quantifying } \\
\text { the performance of the optimal ( } s, u) \text {-policy at a } \\
\text { given level of imperfectness can be used in practice to } \\
\text { obtain the economic value of a certain level of } \\
\text { improvement in the predictive model. }\end{array}$ \\
\hline
\end{tabular}


M. Goutham. et.al / Design, Modelling and Fabrication of Advanced Robots 1(1) 2022, 6-14

\begin{tabular}{|c|l|l|l|l|}
\hline 40. & $\begin{array}{l}\text { AI-assistance for } \\
\text { predictive } \\
\text { maintenance of } \\
\text { renewable energy } \\
\text { systems }\end{array}$ & $\begin{array}{l}\text { Won Shin, Jeongyun } \\
\text { Han, Wonjong Rhee. }\end{array}$ & $3^{\text {rd }}$ January 2021 & $\begin{array}{l}\text { Predictive maintenance is a crucial component for the } \\
\text { successful operation of renewable energy systems, } \\
\text { and adopting the latest AI technology is expected to } \\
\text { be inevitable for scaling predictive maintenance to } \\
\text { sufficiently frequent and periodic inspections. This } \\
\text { work, studied a representative case of bearing fault } \\
\text { detection where endoscope images are collected for } \\
\text { the inspection. They considered the The results show } \\
\text { that all factors, specificity, sensitivity, and time } \\
\text { efficiency, can be improved with AI-assistance, for } \\
\text { both the generalist group and specialist group. }\end{array}$ \\
& & &
\end{tabular}

\section{Conclusion}

From the literature study the newly proposed AI based system was proposed with enhanced features. The Artificial intelligence based inspection also has applications in weld joints testing, internal defect analysis and even in structural analysis as well.The project has 3 types of machine setup's namely bridge type microscopic setup and the rail type setup. Initially the machine is calibrated and based on the trained cascade file the test specimen is examined and suitable lightning systems are provided to improve the quality of inspection. The proposed CAD model of the project shows the microscopic setup of the Artificial Intelligence based inspection Machine. The future scope of the project involves three dimensional inspections which can be used in automobile part inspection, involving the use of camera ' $\mathrm{s}$ in all three dimensions and even converting the captured image into 3D models which could be processed and updated based on the requirements of the future.

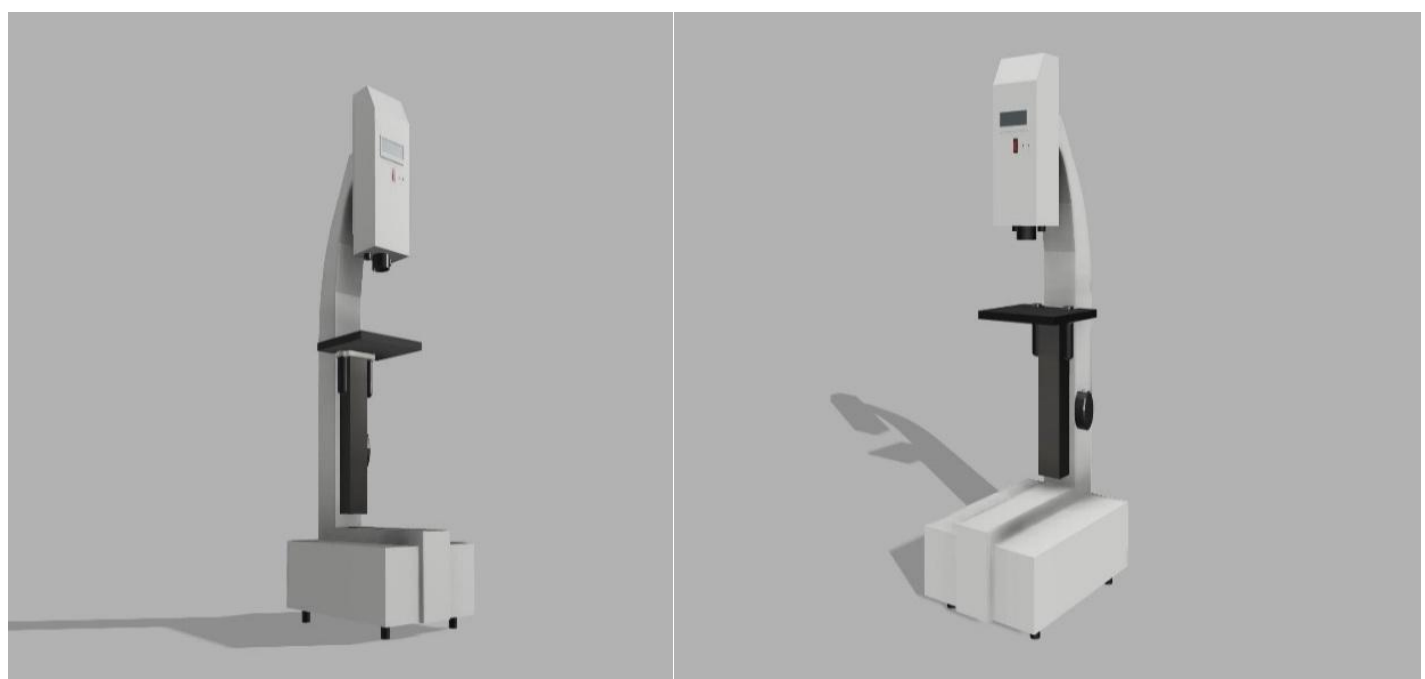

FIGURE 3.Isometric view of the proposed system

\section{References}

1. Hiroya Maeda ,YoshihideSekimeto ,Toshikazu Seto ,Takehiro Kashiyama , Hiroshi Omata ,"Road Damage inspection”, International Conference held on January 2018 .

2. AmurtaMohite ,Atherva Kulkarni ,RutwikChithis ,Swapnil Mane, ShubhamAsabe, “Ai Inspection: Computer Vision For Visual inspection ", International Conference held on January 2021

3. Hanzawa Yuki, Ikeda Yasuyuki, KirutaManashi, Hasiwaga Yuki , "Inspection machine defect Detection based on deep learning ", Conference held on October 2021.

4. JochenBoing, ThrobjornBorggrafe, GunterBeitinger ,JochenDeuse, "Inspection machine based on Machine learning and cloud computing",OMRON TECHNICS Vol.51 September 2019.

5. AB Plastomech ,Bangalore "Special purpose inspection machine", Advanced Engineering Informatics ,2020 .

6. Jong Hyuk lee ,Hyum Min On ,Min Young Kim, “3D defect detection using photometric stereo illusion”, International Conference on Artificial Intelligence 2019

7. VladimirsSatrevics, GundarsKulikkovskis ,Oskars Oss, "Quality control inspection opportunities using deep learning" , $24^{\text {th }}$ World Multi conference on Systematics Cybernets and informatics 2020.

8. Sarthak J Shetty, "Fracture Detection using machine vision and neural network", International Conference on January 2019.

9. Diego Gonzales, "Machine Vision application in Industrial application", International Conference held on January 2021.

10. G Shanmugasundar, M Dharanidharan, D Vishwa, A Jayaprakash and P Abimanyu , 2020, "Design and Finite Element 
Analysis of Prosthetic Hand Controlled by Wireless Gestures for Differently-abled People” IOP Conference Series: Materials Science and Engineering 923 (2020) 012019 IOP Publishing, Doi:10.1088/1757-899X/923/1/012019.

11. G. Shanmugasundar, G. Fenneth Moses, S. Jayachandran, V.D. Rathnavel Subramanian and R. Rajagopalan, 2020 "Design and Fabrication of Solar Powered Multi-Purpose Agricultural Vehicle with IOT Control" , Journal of Advanced Research in Dynamical and Control Systems, Volume 12, Pages: 1928-1933.

12. G.Shanmugasundar , R.Yokesh , S.Yuvaranjith , R.Barath, S.Balasubramanian (2020), Design and Fabrication of Intelligent Gas stove for women safety , International journal of pharmaceutical research , https://doi.org/10.31838/ijpr/2020.12.02.0126

13. G.Shanmugasundar, M.Dharanidharan,, D.Vishwa, P. Gokul, (2020), Design, Modelling and Analysis of an Autonomous Ornithopter Robot for Environmental Pollution Monitoring, Interciencia Journal (ISSN: 0378-1844), 45(12 ), PP- 2-10. https://intercienciajournal.com/intercien/index.php/pdf/stream/54un4/1604942593.

14. G. Shanmugasundar, P. Jagadeeshwar, S. Adithya, V. Nagappan, and M. Bhaskar, "Design, fabrication and analysis of personal vacuum assisted climber," in Journal of Physics: Conference Series, 2019, vol. 1362, no. 1, doi: 10.1088/17426596/1362/1/012057.

15. G. Shanmugasundar, R. Sivaramakrishnan, S. Meganathan, and S. Balasubramani, "Structural optimization of an five degrees of freedom (T-3R-T) robot manipultor using finite element analysis," in Materials Today: Proceedings, 2019 , vol. 16, pp. 1325-1332, doi: 10.1016/j.matpr.2019.05.231.

16. G. Shanmugasundar, R. Sivaramakrishnan, and S. Balasubramani, "Method of Trajectory Generation of a Generic Robot using Bresenham's Circle Algorithm,” Indian J. Sci. Technol., vol. 9, no. 48, 2017, doi: 10.17485/ijst/2016/v9i48/108476.

17. R. Sridhar, G. Shanmugasundar, and A. Srithar, "A Geometrical Modular Design for Handling of LPG Cylinders using Nested Kinematic Robotic Gripper," in Indian Journal of Science and Technology, 2016, vol. 9, no. 48, doi: 10.17485/ijst/2016/v9i48/108474.

18. G. Shanmugasundar and R. Sivaramakrishnan, "Design and analysis of a newly developed seven degree of freedom robot for inspection,” Int. J. Control Theory Appl., vol. 9, no. 24, pp. 393-402, 2016.

19. Lokhande, DrAmol, Dr C. Venkateswaran, Dr M. Ramachandran, C. Vidhya, and R. Kurinjimalar. "A Study on Various Implications on Reusing in Manufacturing." REST Journal on Emerging trends in Modelling and Manufacturing 7, no. 2 (2021).

20. G. Shanmugasundar and R. Sivaramakrishnan, "Computer aided modelling and simulation of a generic robot for inspection,” Int. J. Appl. Eng. Res., vol. 10, no. 24, pp. 44049-44056, 2015.

21. G. Shanmugasundar, R. Sivaramakrishnan, R. Sridhar, and M. Rajmohan, "Computer Aided Modelling and Static Analysis of an Inspection Robot," in Applied Mechanics and Materials, 2015, vol. 766-767, doi: 10.4028/www.scientific.net/amm.766-767.1055.

22. G. Shanmugasundar, R. Sivaramakrishnan, and M. Rajmohan, "Computer aided simulation for workspace plot of a newly designed inspection robot," in 2014 IEEE International Conference on Computational Intelligence and Computing Research, IEEE ICCIC 2014, 2015, doi: 10.1109/ICCIC.2014.7238470. 